\title{
Revisions to Mid-Carboniferous Heath and Tyler Formations Stratigraphy and Nomenclature, Big Snowy Trough, Central Montana, USA
}

\author{
Bottjer, Richard J., Coal Creek Resources, Inc., Denver, CO, USA, rjbottjer@coalcreekresources.com \\ Doughty, P.T., PRISEM Geoscience Consulting, Spokane, WA, USA, teddoughty@prisemgeoconsulting.com \\ Grader, G.W., PRISEM Geoscience Consulting, Spokane, WA, USA, georgewgrader@prisemgeoconsulting.com \\ Di Pasquo, Mercedes, Laboratorio de Palinoestratigrafía y Paleobotánica, CONICET, Buenos Aires, Argentina, \\ medipa@cicyttp.org.ar \\ Rice, B.J., University of Idaho, Moscow, ID, USA, rice7682@vandals.uidaho.edu
}

\begin{abstract}
Mid-Carboniferous black shales in central Montana were included in the Heath Formation of the Big Snowy Group by Scott in 1935. Poor surface exposures have led to debate as to: 1) the existence of an unconformity between the Heath and the overlying Tyler formations, 2) the age of similar Tyler facies, and 3) whether strata assigned to the Tyler are mappable. New subsurface cores provide data that facilitate an internal subdivision of the Heath and enhance understanding of the relationship between Heath and Tyler strata.
\end{abstract}

Historically, the definition of the base of the Heath has been based on a color change from bright green shales in the Otter to black shales in the Heath. This is problematic in that the contact is not exposed at the surface and is not mappable with precision. This study proposes that the base of the Heath / top of the Otter be re-defined as the top of a laterally persistent limestone bed that is regionally correlative in the subsurface and is mappable at the surface (Scott, 1935). All of the bright green mudrocks of the type Otter are below this limestone, and all of the black mudrocks of the type Heath are above this limestone.

The top of the Heath Formation should be defined as the sequence boundary above which sandstones and large wood fragments are present. The clastic-bearing unit above the Heath, deposited in incised valleys, is assigned to the Stonehouse Canyon Member of the Tyler. The Bear Gulch Limestone is within the Stonehouse Canyon and it should be included in the Tyler. The overlying Cameron Creek is distinguished by the predominance of red and green mudrocks and overlies a regional unconformity.

New data allow for an informal subdivision of the Heath. These units, in ascending order, are the lower Heath, Van Dusen zone, Cox Ranch Oil Shale Interval (expanded from the original definition), Red Hill Carbonate (includes the Loco Ridge Gypsum bed), Winnett Shale (lowstand basin fill), and upper Heath. These cyclic, mudrock-dominated strata record an overall rising relative sea level during Heath deposition and a changing climate from moderately humid during deposition of the Van Dusen to very arid during deposition of the Red Hill Carbonate. Large eustatic sea level falls resulted in sequence boundaries at the Heath-Stonehouse Canyon and Stonehouse CanyonCameron Creek contacts. 


\section{REFERENCES}

Ahern, J.P., and C.R. Fielding, 2019, Onset of the late Paleozoic glacioeustatic signal: A stratigraphic record from the paleotropical, oil-shale-bearing Big Snowy Trough of central Montana, U.S.A.: Journal of Sedimentary Research, v. 89, p. 761-783

Beekly, E.K., 1955, Heath-Amdsen boundary on central Montana uplift at Big Wall Field, Musselshell County, Montana (abs.): AAPG Bulletin, v. 39, No. 4, p. 532

Bottjer, R. J., 2017, Recommended revisions to mid-Carboniferous stratigraphy of the Big Snowy trough, central Montana, USA: AAPG Search and Discovery Article \#51422, Posted September 11, 2017, adapted from oral presentation given at AAPG 2017 Rocky Mountain section meeting, Billings, MT, June 25-27, 2017

http://www.searchanddiscovery.com/pdfz/documents/2017/51422bottjer/ndx bott jer.pdf.html?q=\%252BauthorStrip\%253Abottjer

Bottjer, R.J., and P.T. Doughty, 2017, Stratigraphic control of reservoir development, Heath Formation, central Montana, USA, in Katz, D. (ed.), Hot plays of the Rocky Mountain region and beyond: Rocky Mountain Association of Geologists, 2017 Fall Symposium Guidebook, September 28, 2017, p. 111-150

Bottjer, R.J., J. E. Zumberge, J. B. Curtis, I. C. Scotchman, and P. F. Purrazzella, 2016, Interbedded source and reservoir rocks in a hybrid tight oil petroleum system: Mississippian Heath Formation, central Montana, USA: AAPG Search and Discovery Article \# 51234, posted March 28, 2016, adapted from poster presentation given at AAPG 2015 Annual Convention and Exhibition, Denver, CO, May 31 - June 3, 2015

http://www.searchanddiscovery.com/documents/2016/51234bottjer/ndx bottjer.p $\underline{\mathrm{df}}$

Clark, J.P., and R.P. Philp, 1989, Geochemical characterization of evaporate and carbonate depositional environments and correlations of associated crude oils in the Black Creek Basin, Alberta: Bulletin of Canadian Petroleum Geology, v. 37, p. $401-416$

Craig, L.C., 1972, Mississippian System, in, Mallory, W. W., Geologic Atlas of the Rocky Mountain Region: Rocky Mountain Association of Geologists, p. 100-110

Derkey, P.D., F.N. Abercrombie, S.M. Vuke, and J.A. Daniel, 1985, Geology and oil shale resources of the Heath Formation, Fergus County, Montana: Montana Bureau of Mines and Geology Memoir 57, 100p. 
Dumoulin, J.A., C. A. Johnson, K. D. Kelley, P. Jarboe, P. Hackley, C. Scott, and J. F. Slack, 2017, Transgressive-regressive cycles in the metalliferous, oil shalebearing Heath Formation (Upper Mississippian), central Montana: Stratigraphy, v. 14, nos. 1-4, p. $97-122$

Easton, W. H., 1962, Carboniferous formations and faunas of central Montana: U.S. Geological Survey Professional Paper 348, 126 p.

Freeman, O.W., 1922, Oil in the Quadrant formation in Montana: Engineering Mining Journal-Press, V112, No. 19, p. 825-827

Gardner, L.S., 1959, Revision of Big Snowy Group in central Montana: AAPG Bulletin, v. 43, no. 2, p. 329-349

GeoMark, 2011, Petroleum geochemistry of crude oils from the Central Montana Trough: Proprietary study, 25 pp., GerMark Research, Houston, TX

Grogan, E.D., and R. Lund, 2002, The geological and biological environment of the Bear Gulch Limestone (Mississippian of Montana, USA) and a model for its deposition: Geodiversitas, v. 24, p. 295-315

Hill, R.J., D. M. Jarvie, J. Zumberge, M. Henry, and R. M. Pollastro, 2007, Oil and gas geochemistry and petroleum systems of the Fort Worth Basin: AAPG Bulletin, v. 91, no. 4, p. 445-473

Horner, J. R. 1979. Stratigraphic position of the Bear Gulch Limestone (Lower Carboniferous) of central Montana, in Dutro, J.T., and H.W. Pfefferkorn (eds.), Ninth International congress on Carboniferous stratigraphy and geology: University of Illinois at Urbana-Champaign, Southern Illinois University Press, copyright 1984, Compte Rendu, Vol. 5 Paleontology, Paleoecology, Paleogeography, p. 427-436

Koopmans, M. P., J. Köster, H. M. E. Van Kaam-Peters, F. Kenig, S. Schouten, W. A. Hartgers, J. W. de Leeuw, and J. S. Sinninghe Damsté, 1996a, Diagenetic and catagenetic products of isorenieratene: Molecular indicators for photic zone anoxia: Geochimica et Cosmochimica Acta, v. 60, p. 4467-4496

Koopmans, M. P., S. Schouten, M. E. L. Kohnen, and J. S. Sinninghe Damste, 1996b, Restricted utility of aryl isoprenoids as indicators for photic zone anoxia: Geochimica et Cosmochimica Acta, v. 60, no. 23, p. 4873-4876

Maughan, E.K., 1989, Geology and petroleum potential of the central Montana province: U.S. Geological Survey Open-File Report OF 88-450 N, 41p. \& 2 plates 
Maughan, E. K., 1984, Paleogeographic setting of Pennsylvanian Tyler Formation and relation to underlying Mississippian rocks in Montana and North Dakota: AAPG Bulletin, v. 68, No. 2, p. 178-195

Maughan, E. K., and A. E. Roberts, 1967, Big Snowy and Amsden Groups and the Mississippian-Pennsylvanian boundary in Montana: U.S. Geological Survey Professional Paper 554-B, 27p.

Moldowan, J.M., W.K. Seifert, and E.J. Gallegos, 1985, Relationship between petroleum composition and depositional environment of petroleum source rocks: AAPG Bulletin, V. 69, No. 8, p. 1255-1268

Mundt, P.A., 1956a, Heath-Amsden strata in central Montana: AAPG Bulletin, v. 40, No. 8, p. 1915-1934

Mundt, P.A., 1956b, The Tyler and Alaska Bench Formations, in Foster, D.I., central Montana: Billings Geological Society, Seventh Annual Field Conference, August 16-18, 1956, p. 46-51

Obermajer, M., K.G. Osadetz, M.G. Fowler, J. Silliman, W. B. Hansen, and M. Clark, 2002, Delineating compositional variabilities among crude oils from central Montana, USA, using light hydrocarbon and biomarker characteristics: Organic Geochemistry, v. 33, p. 1343-1359

Obermajer, M., J. Silliman, K.G. Osadetz, and W.B. Hansen, 2000, Organic geochemistry and biomarker compositions of crude oils from eastern and central Montana, USA, in Schalla, R.A., and E.H. Johnson (eds.), Montana and Alberta thrust belt and adjacent foreland: $50^{\text {th }}$ Anniversary Symposium, Montana Geological Society, Billings, MT, Volume 1, p. 47-63

Porter, K.W., and E.M. Wilde, 1999, Geologic map of the Musselshell 30' x 60' quadrangle, central Montana: Montana Bureau of Mines and Geology Open-File Report 386, 22 p., 1 sheet, scale 1:100,000, Revised 2005.

Porter, K.W., E.M. Wilde, and S.M. Vuke, 1996, Preliminary geologic map of the Big Snowy Mountains 30' x 60' quadrangle, central Montana: Montana Bureau of Mines and Geology, Open File Report MBMG 341, Revised 2005, 15 pp. \& 1 plate

Rygel, M.C., C. R. Fielding, T. D. Frank, and L.P. Birgenheier, 2008, The magnitude of Late Paleozoic glacioeustatic fluctuations: A synthesis: Journal of Sedimentary Research, v. 78, p. 500-511

Schwark, L., and A. Frimmel, 2004, Chemostratigraphy of the Posidonia black shale, SW Germany II: Assessment of extent and persistence of photic-zone 
anoxia using aryl isoprenoids distributions: Chemical Geology, v. 206, p. 231248

Scott, H.W., 1935, Some Carboniferous stratigraphy in Montana and northwestern Wyoming: Journal of Geology, v. 43, No. 8, p. 1011-1032

Sinninghe Damste, J.S., F. Kenig, M.P. Koopmans, J. Koster, S. Schouten, J.M. Hayes, and J. W De Leeuw, 1995, Evidence for gammacerane as an indicator of water column stratification: Geochemica Cosmochemica Acta, V. 59, No. 9, p. $1895-1900$

Sloss, L.L., 1963, Sequences in the cratonic interior of North America: GSA Bulletin, V. 74, p. 93-113

Smith, D.L., and E. H. Gilmour, 1979, The Mississippian and Pennsylvanian (Carboniferous) Systems in the United States - Montana: US Geological Survey Professional Paper 1110-M-DD, p. X1-X32

Stanton, P.T., and M.R. Silverman, 1989, Sedimentology, diagenesis, and reservoir potential of the Pennsylvanian Tyler Formation, central Montana, in Coalson, E.B., S.S. Kaplan, C.W. Keighin, C.A. Oglesby, and J.W. Robinson (eds.), Petrogenesis and petrophysics of selected sandstone reservoirs of the Rocky Mountain region: Rocky Mountain Association of Geologists, 1989 Annual Guidebook, p. 29-48 \& p. 304-307

Summons, R.E., and T.G. Powell, 1987, Identification of aryl isoprenoids in source rocks and crude oils: Biological markers for the green sulphur bacteria: Geochemica Cosmochimica Acta, v. 51, p. 557-566

Vuke, S.M., K. W. Porter, J. D. Lonn, and D. A. Lopez, 2007, Geologic map of Montana: Montana Bureau of Mines and Geology, Geologic Map 62, 2 plates, 73 pp.

Williams, L. A., 1983, Deposition of the Bear Gulch Limestone: A Carboniferous plattenkalk from central Montana: Sedimentology, v. 30, p. 843-860 


\section{\#302 Revisions to Mid-Carboniferous Heath and Tyler Stratigraphy and Nomenclature, Big Snowy Trough, Central Montana, USA}

Bottjer, Richard J., Coal Creek Resources, Inc., Denver, CO, USA, rjbottjer@coalcreekresources.com

Doughty, P.T., PRISEM Geoscience Consulting, Spokane, WA, USA, teddoughty@prisemgeoconsulting.com

Grader, G.W., PRISEM Geoscience Consulting, Spokane, WA, USA, georgewgrader@prisemgeoconsulting.com

Di Pasquo, Mercedes, Laboratorio de Palinoestratigrafía y Paleobotánica, CONICET, Buenos Aires, Argentina, medipa@cicyttp.org.ar

Rice, B.J., University of Idaho, Moscow, ID, USA, rice7682@vandals.uidaho.edu

\section{Acknowledgements}

Cirque Resources

Lynn Peyton

Peter Purrazzella (Stratum, formerly Weatherford Labs)

lain Scotchman (consultant, formerly Statoil)

Don Rasmussen

George Hampden

John Rhoades, Jeannine Honey, Dawn Ostrye (USGS Core Research Center)

Gus Gustason \& Bob Larsen (Enerplus)

Orion Skinner (Whiting)

Mitch Meyer (Three Forks)

Justin Ahern (University of Nebraska, Lincoln)

Chris Fielding (University of Nebraska, Lincoln)

Dave Eby (consultant)

Jim Suydham (Sunburst Consulting)

MBMG Staff - cuttings

Jim Halvorsen (MBOGC, Billings)

John Curtis (Geomark)

John Zumberge (Geomark)

Graham McClave (Augustus Energy)

Dave Bowen (Montana State Univ.)

Devon Orme (Montana State Univ.)

Multiple Landowners that allowed access to private lands 


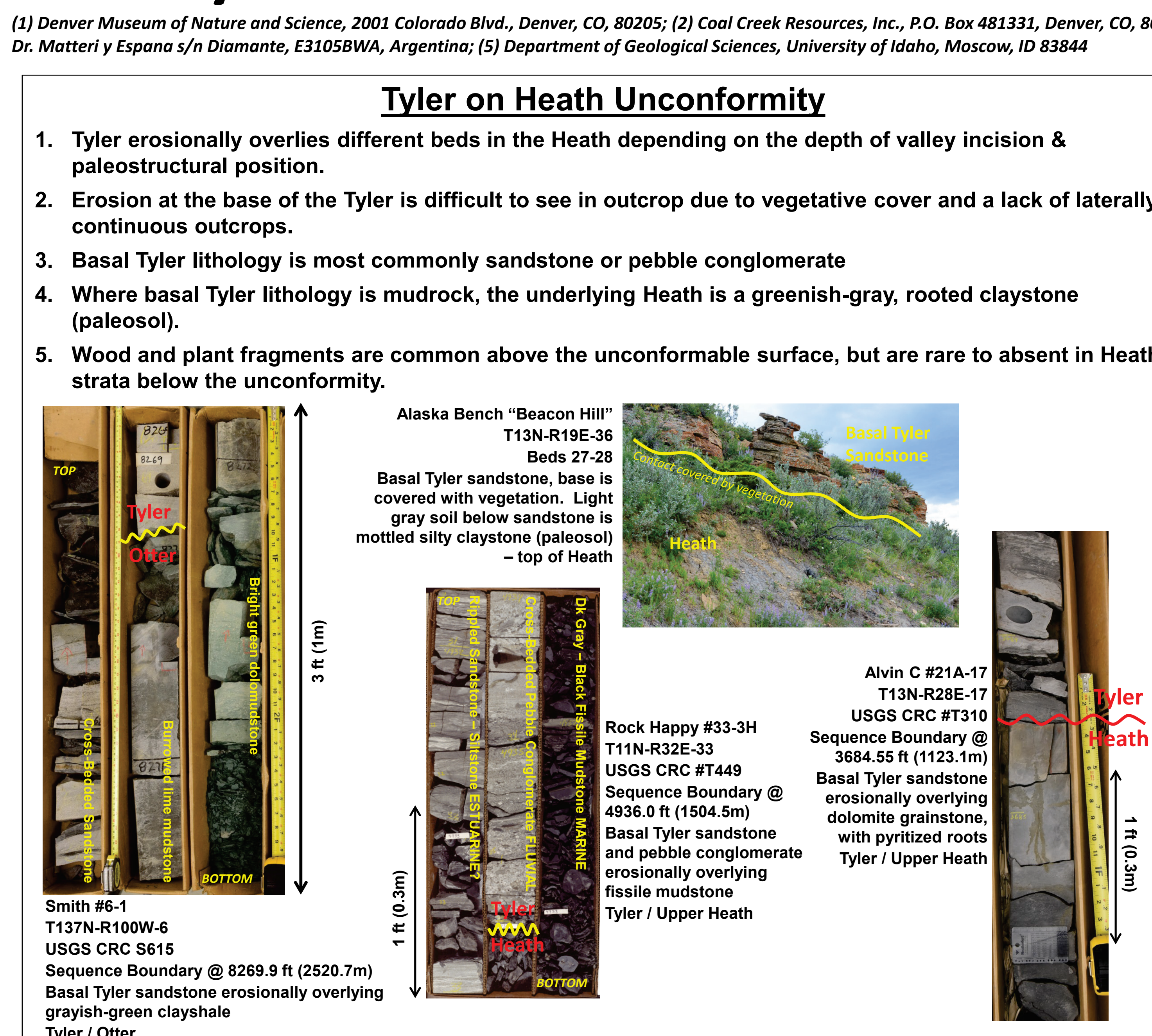

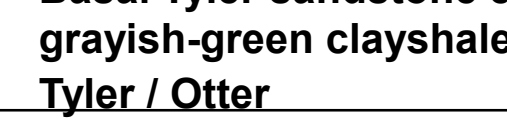

Tyler - Cameron Creek Lithofacies

Maroon to brick red, light gray, grayish-green mudrocks

Sandstones, fine- to crs-grained, local pebble conglomerate, red - It. gray - tan, abdnt limestone clasts

Sandstones are cross-bedded, ripple cross-laminated, commonly fossiliferous

Abundant oxidized wood fragments

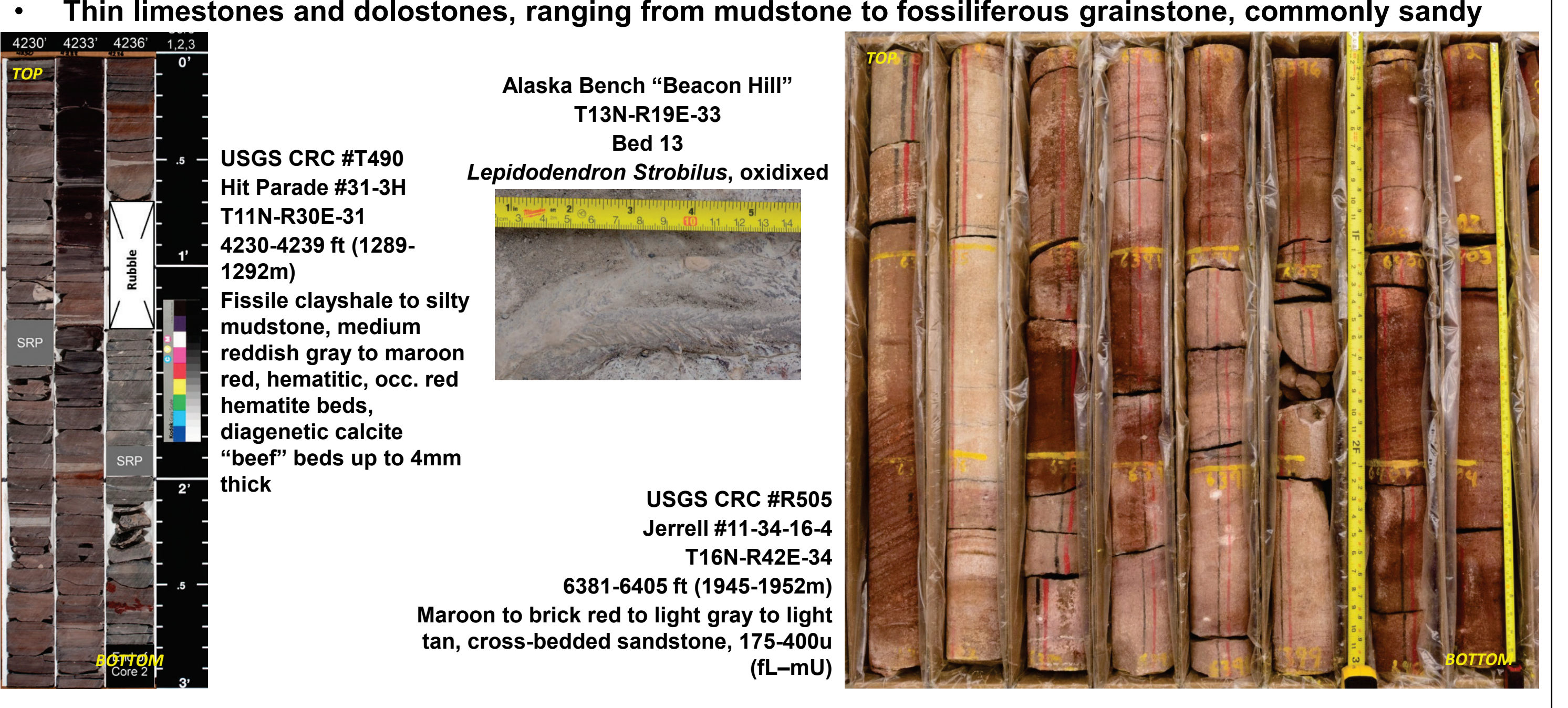

Tyler - Stonehouse Canyon Lithofacies

Dark gray to black mudrocks, fissile clayshale, calcareous mudstone, locally sideritic

Sandstones, fine- to coarse-grained, local pebble conglomerate, light gray to tan

High energy cross-bedded facies and soft-sediment

Thin limestones and dolostones, ranging from mudstone to fossiliferous grainstone

Beds are laterally discontinuous - highly channelized (multiple incised valleys)
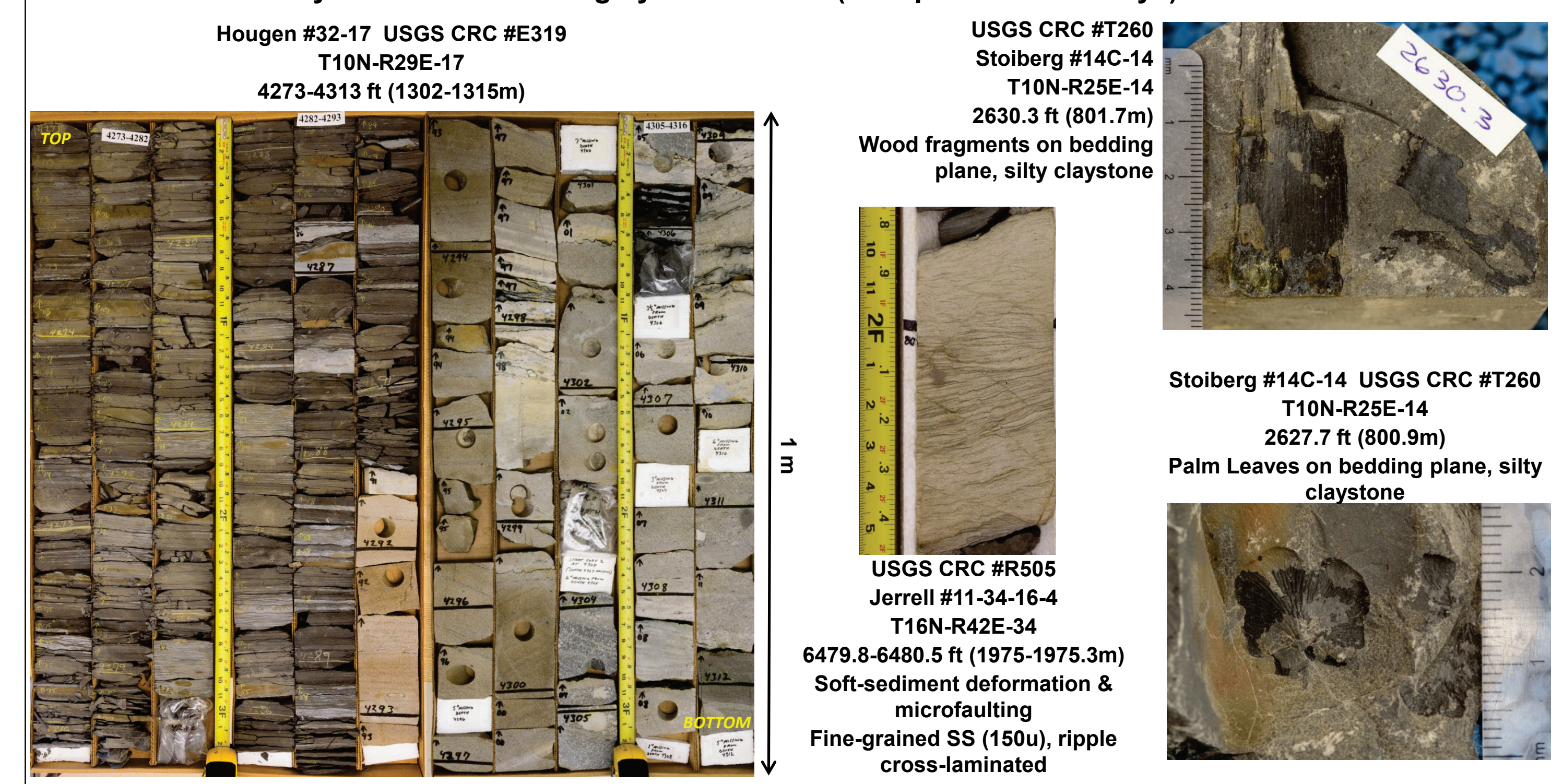

\section{CONCLUSIONS}

The Heath - Otter contact is redefined as top of cream-tan oolitic limestone bed that is correlated from the Judith Basin to the Williston Basin, effectively separates overlying dark gray mudrocks (Heath) from underlying bright green mudrocks (Otter), and is a mappable surface.

The Heath and Tyler are separated by a regional unconformity and are distinct mappable units. Heath strata are marine limestones and mudrocks that are laterally continuous over long distances. Tyler strata are predominantly fluvial and estuarine sandstones and mudrocks deposited in incised valleys that have limited areal distribution.

Multiple new continuous cores facilitate a detailed subdivision of Heath strata (building on previous work of Derkey, et al., 1985)

Heath is subdivided into informal units, in ascending order, lower Heath, Van Dusen, Cox Ranch, Red Hill Carbonate, Winnett Shale, and upper Heath.

Lower Heath strata (i.e. Van Dusen \& Cox Ranch) are laterally continuous

Middle Heath strata (i.e. Red Hill Carbonate \& Loco Ridge Gypsum) are affected by lateral facies changes \& forced regression

Up-section trend towards dryer \& hotter conditions culminating in evaporation of Big Snowy Trough at end of Red Hill Carbonate deposition

Cyclic sedimentation in the Heath is indicative of the onset of the Late Paleozoic Ice Age (Ahern and Fielding, 2019)
Heath - Red Hill Carbonate Lithofacies

Progradational arid-shoreline dolograinstones with sharp bases - forced regression

Anhydrite

Cox Ranch - type cycles in lower parts of Red Hill Carbonate

Some units correlate for
limestones mudstones
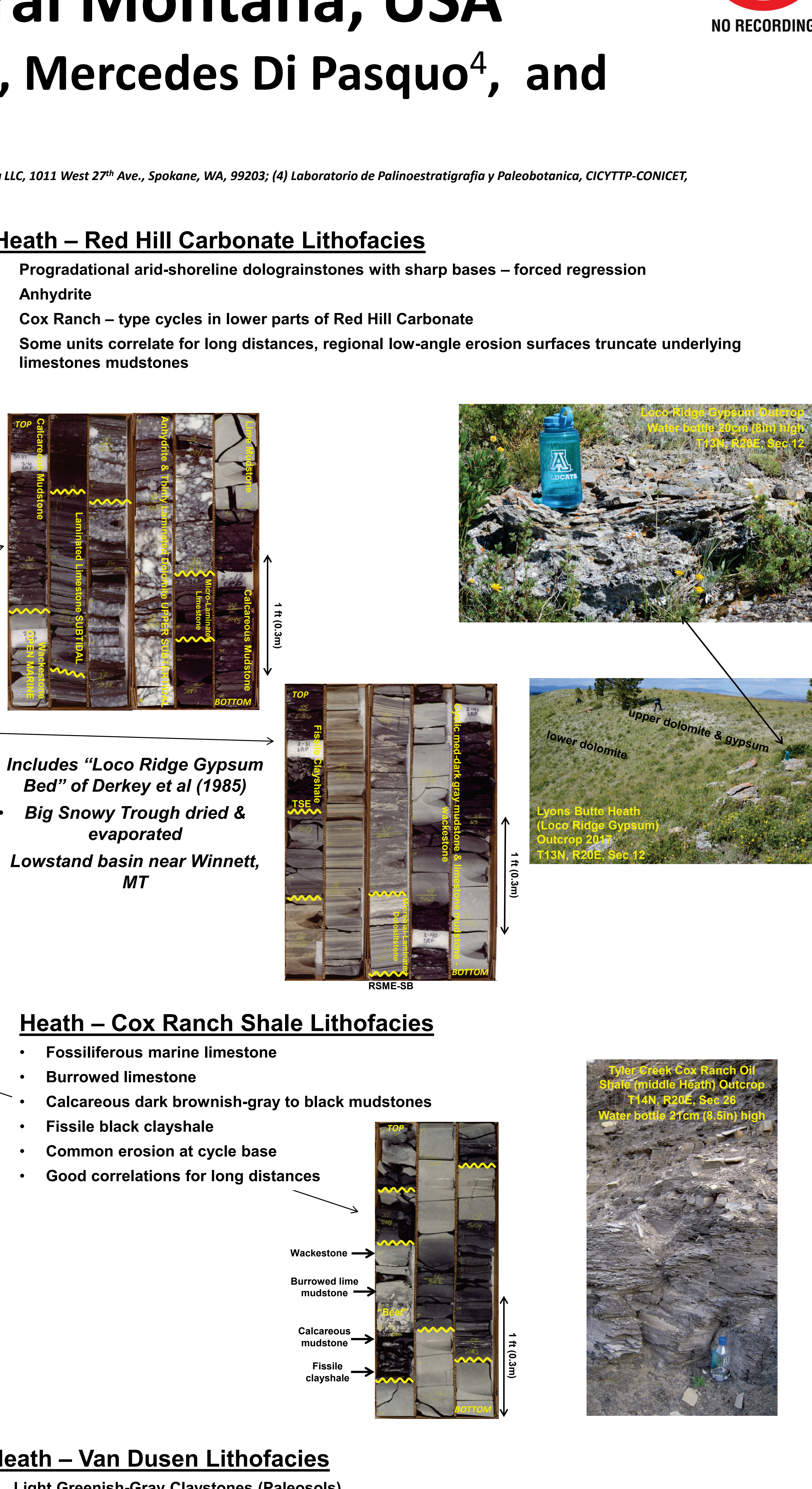

Includes "Loco Ridge Gypsum Bed" of Derkey et al (1985) Big Snowy Trough dried evaporated

MT

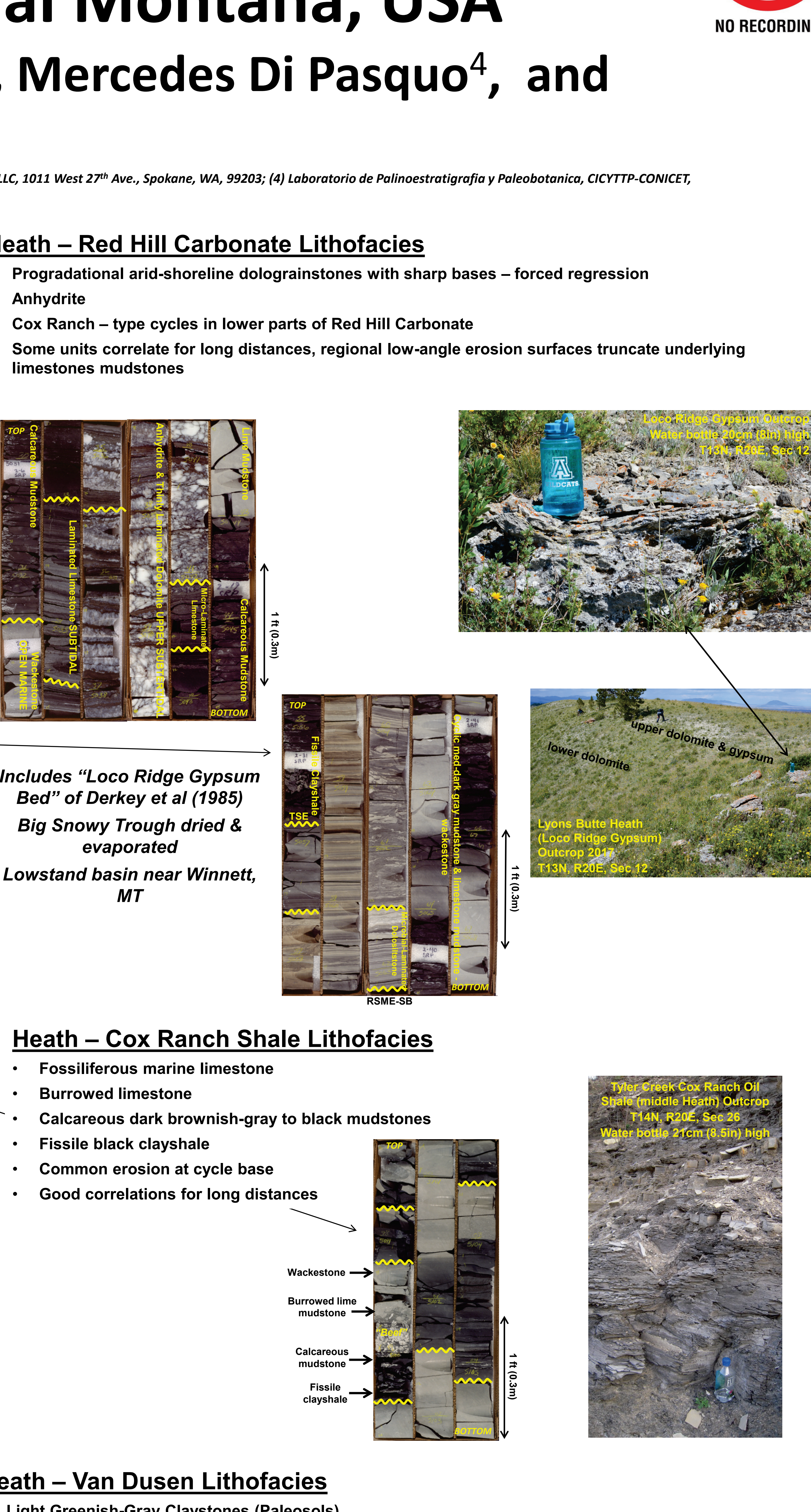

Heath - Cox Ranch Shale Lithofacies

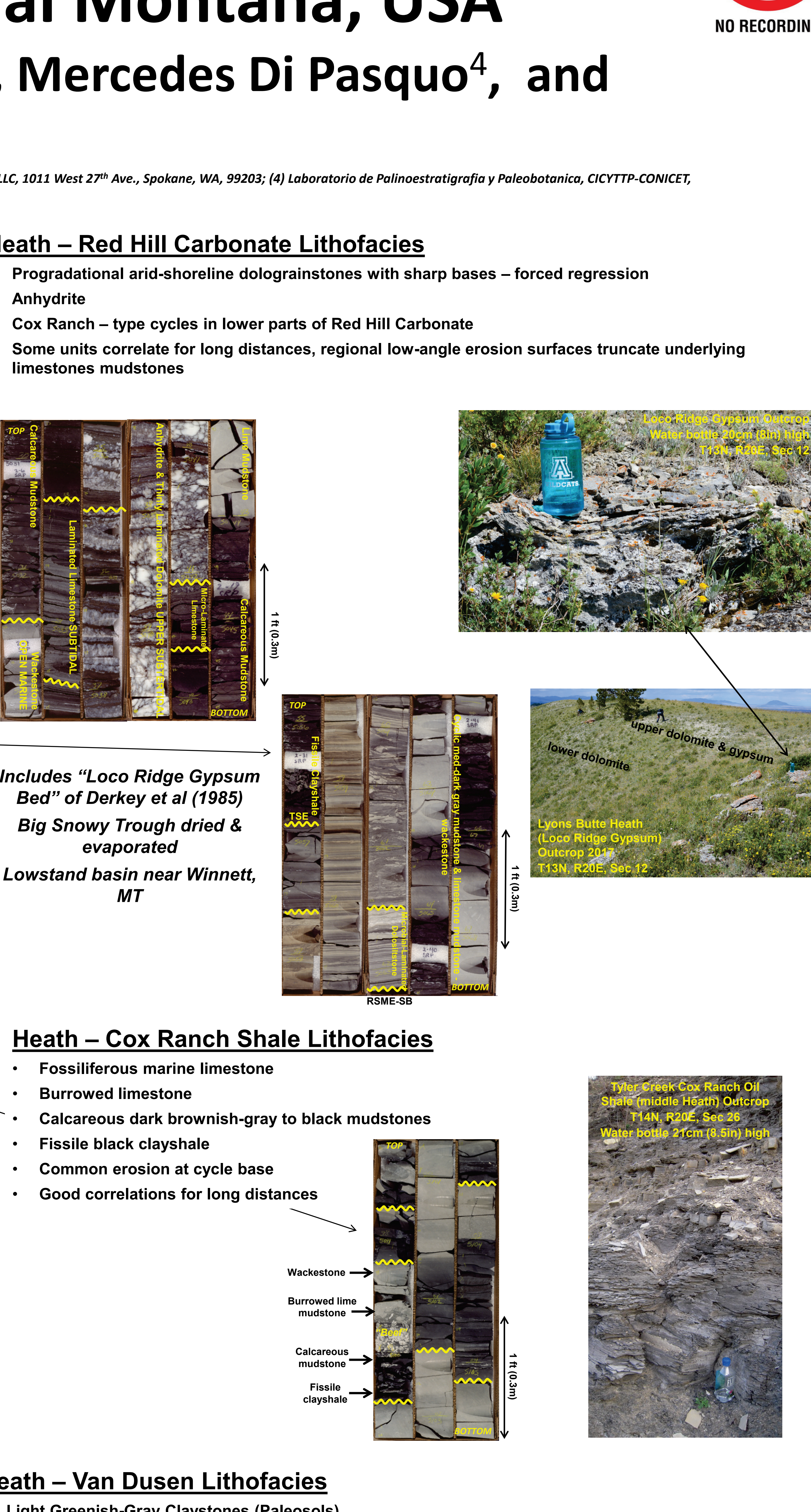

Burrowed limestone

Calcareous dark brown

Common erosion at cycle base

Good correlations for long distances

焉

$$
\text { 곤 }
$$

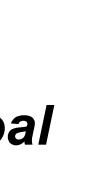$$
\text { 西 }
$$

Heath - Van Dusen Lithofacies

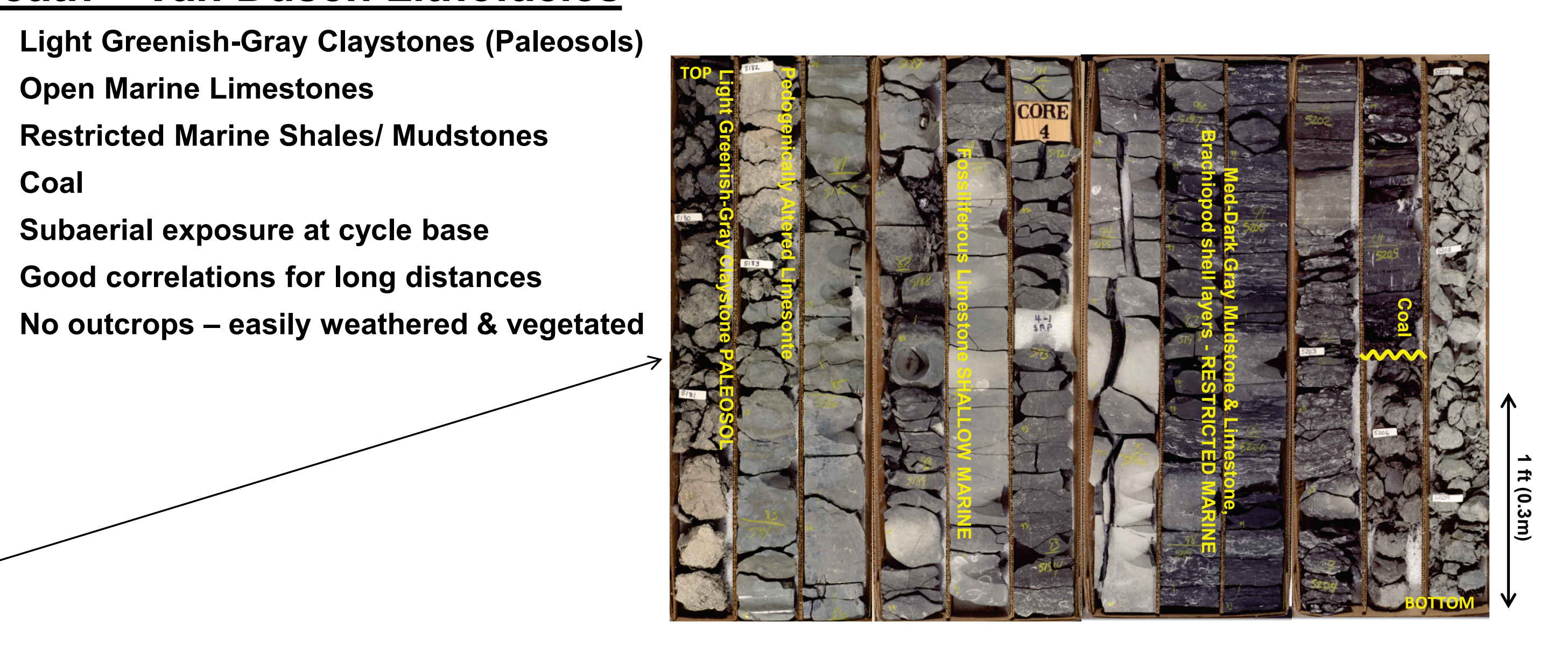

Heath - Oils and Source Rocks Organic Geochemistry Analysis of $>\mathbf{5 0}$ produced oils and source rock extracts from Heath and Tyler cores an reservoirs by Geomark

Family $3=$ Red Hill Car Family 4 = Cox Ranch Oil Sta (high C27, low (29) - more shelfal environ. Both contain aryl isoprenoids - PZE (photic zone euxinia)

Both contain Gammacerane (a C30 Triterpane) - stratified water column Gammacerane, aryl isoprenoids, and C34 extended Hopanes associated with hypersaline, evaporitic, restricted environments

Van Dusen extracts = biomarkers indicate a more terrestrial/coaly source CONCLUSION: Restricted marine environment with stratified water column and photic zone anoxia and/or euxinia

$$
\text { 害 }
$$

